\title{
Effect of High Density Planting and Weed Management Practices on Productivity and Economic Analysis of Bt Cotton
}

\author{
B. Madavi ${ }^{1}$, P. Leela Rani ${ }^{2 *}$, G. Sreenivas ${ }^{3}$ and K. Surekha ${ }^{4}$ \\ ${ }^{1}$ Department of Agronomy, College of Agriculture, ${ }^{2}$ AICRP on Weed Management, ${ }^{3}$ Agro \\ Climate Research Centre, ARI, ${ }^{4}$ Indian Institute of Rice Research, Rajendranagar, \\ Hyderabad, Telangana, India \\ *Corresponding author
}

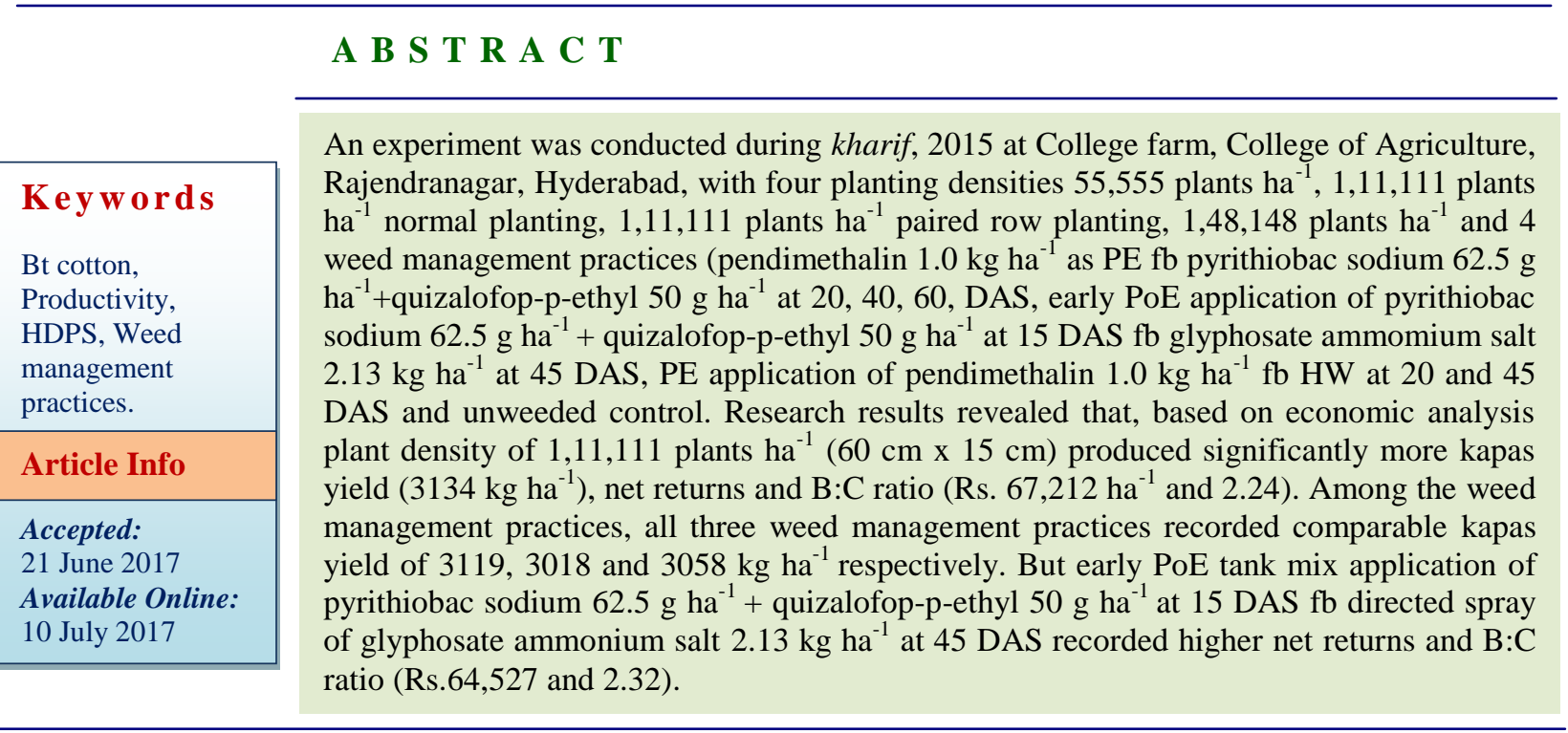

\section{Introduction}

Cotton (Gossypium hirsutum L.) the king of fiber, is one of the momentous and an important cash crop exercising profound influence on economics and social affairs of the world.

Average productivity of cotton in India is 503 $\mathrm{kg} / \mathrm{ha}$ which is low as compared to world average of $733 \mathrm{~kg} / \mathrm{ha}$. Almost 95 per cent Indian cotton farmers are using the genetically modified Bt cotton. However, this $\mathrm{Bt}$ period also registered a marked increase in the instability in production (Narala and Reddy, 2011) as the cost of cotton production is escalating due to increased labour demand, increased labour costs, increased seed costs, and increased costs for cotton picking and nutrient requirements.

The high density planting system (HDPS) is now being conceived as an alternate production system having a potential for improving productivity and profitability (Pradeep kumar et al., 2017), increasing efficiency, reducing input costs and minimising risks associated with India's cotton production system. 
Optimum cotton yield and quality for highdensity planting cotton requires good weed control throughout the growing season. Cotton being a wide spaced and long duration crop suffers from heavy weed competition during the early stages of crop growth. Critical period of crop weed competition is 60 to 70 days from sowing, which may cause yield loss from 40 to 85 per cent depending upon the nature and intensity of weeds. Most often due to incessant rains during kharif season; hand weeding and intercultivation (IC) become difficult in cotton. Further, labours being scarce and costly, growers are forced to fall back on chemicals for weed control. Therefore, farmers are need of selective post emergence broad spectrum herbicide/herbicide mixtures. HDPS will provide a soil canopy in about 30 days as compared to 60-75 days for conventional row widths, which will shade out weeds and reduce their competitiveness as lower weed density under high density planting system was recorded with pre emergence application of pendimethalin $1 \mathrm{~kg} \mathrm{ha} \mathrm{ha}^{-1}+$ one inter cultivation+one hand weeding+1 post emergence spray of tank mixed pyrithiobac sodium $75 \mathrm{~g} \mathrm{ha}^{-1}$ and quizalofop ethyl $50 \mathrm{~g} \mathrm{ha}^{-}$ ${ }^{1}$ (Venugopalan et al., 2013).

So vigilant production and economic strategies are important for cotton growing farmers due to expanding cost of cultivation and stagnating productivity. Keeping these points in view an effort was made to find out the optimum plant density with suitable weed management practice.

\section{Materials and Methods}

An experiment was conducted during kharif, 2015 at College farm, College of Agriculture, Rajendranagar, Hyderabad (The farm is geographically situated an altitude of $542.6 \mathrm{~m}$ above mean sea level on $18^{\prime} 50^{\circ} \mathrm{N}$ latitude and $77.53^{\circ} \mathrm{E}$ longitude). The soil of the experimental field was sandy loam in texture, low in available $\mathrm{N}\left(250 \mathrm{~kg} \mathrm{ha}^{-1}\right)$, medium in phosphorus (21.68 $\left.\mathrm{kg} \mathrm{P}_{2} \mathrm{O}_{5} \mathrm{ha}^{-1}\right)$ and high in potassium $\left(685.6 \quad \mathrm{~kg} \quad \mathrm{~K}_{2} \mathrm{O} \quad \mathrm{ha}^{-1}\right)$. The treatments comprised of four planting densities 55,555 plants $\mathrm{ha}^{-1}\left(\mathrm{D}_{1}\right), 1,11,111$ plants $\mathrm{ha}^{-1}\left(\mathrm{D}_{2}\right)$ normal planting, 1,11,111 plants ha ${ }^{-1}\left(\mathrm{D}_{3}\right)$ paired row planting, 1,48,148 plants $\mathrm{ha}^{-1}\left(\mathrm{D}_{4}\right)$ and weed management practices (pendimethalin $1.0 \mathrm{~kg} \mathrm{ha}^{-1}$ as pre emergence $\mathrm{fb}$ pyrithiobac sodium $62.5 \mathrm{~g}$ ha ${ }^{1}$ +quizalofop-p-ethyl $50 \mathrm{~g} \mathrm{ha}^{-1}$ at 20, 40, 60, DAS $\left(\mathrm{W}_{1}\right)$, pyrithiobac sodium $62.5 \mathrm{~g}$ ha ${ }^{1}$ +quizalofop-p-ethyl $50 \mathrm{~g} \mathrm{ha}^{-1}$ at 15 DAS as early post emergence fb glyphosate ammonium salt $2.13 \mathrm{~kg} \mathrm{ha}^{-1}$ at 45 DAS $\left(\mathrm{W}_{2}\right)$, pendimethalin $1.0 \mathrm{~kg} \mathrm{ha}^{-1}$ as pre emergence $\mathrm{fb}$ $\mathrm{HW}$ at 20 and 45 DAS $\left(\mathrm{W}_{3}\right)$ and unweeded control $\left(\mathrm{W}_{4}\right)$ in randomized block design (factorial), replicated thrice.. Net return or profit was calculated by subtracting cost of cultivation from the gross returns. Price used for harvest products was minimum support price during the experimental period. The benefit: cost ratio was calculated by dividing the gross returns with cost of cultivation.

\section{Results and Discussion}

\section{Effect of plant densities on yield}

The main and interaction effect of plant densities and weed management practices showed significant influence on yield and economics of $\mathrm{Bt}$ cotton (Tables 1 and 2). Plant density of $1,11,111$ plants $\mathrm{ha}^{-1}$ normal planting $(60 \mathrm{~cm} \times 15 \mathrm{~cm})$ recorded higher kapas yield and was superior over rest of the plant densities viz.1,11,111 plants ha ${ }^{-1}$ paired row planting $(60 \mathrm{~cm} \times 15 \mathrm{~cm}), 1,48,148$ plants $\mathrm{ha}^{-1}(45 \mathrm{~cm} \times 15 \mathrm{~cm})$ and 55,555 plants ha ${ }^{-1}(60$ $\mathrm{cm} \times 30 \mathrm{~cm})$. In turn plant densities of 1 , 48,148 plants $\mathrm{ha}^{-1}$ and 55,555 plants ha ${ }^{-1}$ were on par with each other. Although more plant height, crop drymatter and reduced LAI per plant (Table 1) was noticed with 55,555 
plants $\mathrm{ha}^{-1}(60 \mathrm{~cm} \times 30 \mathrm{~cm})$ at wider spacing, but the increased yield in 1, 11,111 plants ha ${ }^{-1}$ normal planting was due to more number of bolls $\mathrm{m}^{-2}$, boll weight over rest of the densities. Yield increase of $30.31 \%, 29.57 \%$ and $17.20 \%$ was observed when plant density was increased to $1,11,111$ plants ha $^{-1}$ normal planting from plant density of 55,555 plants $\mathrm{ha}^{-1}, 1,48,148$ plants ha ${ }^{-1}$ and $1,11,111$ plants $\mathrm{ha}^{-1}$ paired row planting respectively. Even though, the boll number, boll weight and seed cotton yield plant ${ }^{-1}$ was significantly higher with wider spacing (Pradeep kumaret al., 2017), it could not compensate for the loss in number of plants ha ${ }^{-1}$ and number of bolls $\mathrm{m}^{-2}$, thus recorded lower seed cotton yield $\mathrm{ha}^{-1}$ when compared to high density planting.

\section{Effect of weed management practices on yield}

Higher kapas yield was recorded with pendimethalin (PE) $1.0 \mathrm{~kg} \mathrm{ha}^{-1} \mathrm{fb}$ PoE tank mix application of pyrithiobac sodium $62.5 \mathrm{~g}$ $\mathrm{ha}^{-1}$ +quizalofop-p-ethyl $50 \mathrm{~g} \mathrm{ha}^{-1}$ at 20, 40, 60 DAS and was comparable with pendimethalin $1.0 \mathrm{~kg} \mathrm{ha}^{-1}$ (PE) fb HW at 20 and 45 DAS and early PoE tank mix application of pyrithiobac sodium $62.5 \mathrm{~g} \mathrm{ha}^{-1}+$ quizalofop-p-ethyl $50 \mathrm{~g}$ $\mathrm{ha}^{-1}$ at 15 DAS $\mathrm{fb}$ directed spray of glyphosate ammonium salt $2.13 \mathrm{~kg} \mathrm{ha}^{-1}$ at 45 DAS and were significantly superior over unweeded control treatment.

The yield reduction of $70.34 \%$ was observed from unweeded control treatment. Further, timely and effective control of weeds through herbicides coupled with cultural methods which resulted in better availability of soil moisture and nutrients (Prabhu et al., 2012). Interaction effect of plant densities and weed management practices did not show any significant influence on seed cotton yield and economics in Bt cotton.

\section{Effect of plant densities on economics}

Plant densities exerted significant influence on monetary returns of $\mathrm{Bt}$ cotton cultivation (Table 2). Significantly higher cost of cultivation was noticed with $1,48,148$ plants $\mathrm{ha}^{-1}(45 \mathrm{~cm} \times 15 \mathrm{~cm})$ and was followed by 1 , 11,111 plants $\mathrm{ha}^{-1}(60 \mathrm{~cm} \times 15 \mathrm{~cm})$ normal planting and 1,11,111 plants ha ${ }^{-1}(60 \mathrm{~cm} \times 15$ $\mathrm{cm})$ paired row planting. The lowest cost of cultivation was recorded with 55,555 plants $\mathrm{ha}^{-1}(60 \mathrm{~cm} \times 30 \mathrm{~cm})$.

This reduced cost of cultivation was might be due to reduced seed cost towards purchase of seed. However more gross returns was achieved with $1,11,111$ plants ha ${ }^{-1}(60 \mathrm{~cm} \times 15$ $\mathrm{cm})$ normal planting followed by plant density of $1,11,111$ plants ha ${ }^{-1}(60 \mathrm{~cm} \times 15 \mathrm{~cm})$ paired row planting, 1,48,148 plants ha ${ }^{-1}(45$ $\mathrm{cm} \times 15 \mathrm{~cm})$ and 55,555 plants ha ${ }^{-1}(60 \mathrm{~cm} \times 30$ $\mathrm{cm})$ respectively. This increased gross returns was might be due to more kapas yield per unit area. This was reflected as significantly higher net returns with $1,11,111$ plants ha ${ }^{-1}$ normal planting over rest of the plant densities. This was followed by $1,11,111$ plants $\mathrm{ha}^{-1}$ paired row planting and 55,555 plants $\mathrm{ha}^{-1}$, in turn these two recorded on par net returns. Even though more gross returns were recorded, reduced net returns were obtained with plant density of $1,48,148$ plants $\mathrm{ha}^{-1}$. This reduced net returns were might be due to increased cost of cultivation and reduced kapas yield per unit area at higher plant densities.

Economic analysis showed that, higher B:C ratio was noticed with $1,11,111$ plants $\mathrm{ha}^{-1}$ normal planting followed by 55,555 plants $\mathrm{ha}^{-1}$, $1,11,111$ plants $^{-1} a^{-1}$ paired row planting and $1,48,148$ plants ha ${ }^{-1}$ treatment. 
Table.1 Plant height, crop dry matter, Leaf area index and yield in Bt cotton under varied plant densities and weed management practices kharif, 2015

\begin{tabular}{|c|c|c|c|}
\hline Treatment & \multirow{2}{*}{$\begin{array}{c}\text { Plant } \\
\text { height } \\
(\mathrm{cm})\end{array}$} & \multirow{2}{*}{$\begin{array}{c}\text { Crop } \\
\text { drymatter }_{\left(\text {g plant }^{-1}\right)}\end{array}$} & \multirow[t]{2}{*}{$\begin{array}{l}\text { Leaf area } \\
\text { index }\end{array}$} \\
\hline Plant densities (D) & & & \\
\hline $60 \mathrm{~cm} \times 30 \mathrm{~cm}(55,555)$ & 112 & 76.99 & 1.47 \\
\hline $60 \mathrm{~cm} \times 15 \mathrm{~cm}(1,11,111)$ & 102 & 73.99 & 2.89 \\
\hline $60 \mathrm{~cm} \times 15 \mathrm{~cm}(1,11,111$ Paired row- $45 \mathrm{~cm} \times 75 \mathrm{~cm})$ & 105 & 64.34 & 2.74 \\
\hline $45 \mathrm{~cm} \times 15 \mathrm{~cm}(1,48,148)$ & 110 & 54.18 & 3.55 \\
\hline S. Em \pm & 2.6 & 3.34 & 0.02 \\
\hline $\mathrm{CD}(\mathrm{P}=0.05)$ & NS & 9.69 & 0.10 \\
\hline \multicolumn{4}{|l|}{ Weed Management Practices (W) } \\
\hline $\begin{array}{l}\text { Pendimethalin } 30 \% \text { EC } 1.0 \mathrm{~kg} \mathrm{ha}^{-1} \text { as PE fb PoE } \\
\text { pyrithiobac sodium } 62.5 \mathrm{~g} \mathrm{ha}^{-1}+\text { quizalofop-p-ethyl } 5 \% \\
\text { EC } 50 \mathrm{~g} \mathrm{~h}^{-1} \text { at } 20,40,60 \mathrm{DAS}\end{array}$ & 109 & 82.29 & 3.28 \\
\hline $\begin{array}{l}\text { Pyrithiobac sodium } 10 \% \text { EC } 62.5 \mathrm{~g} \mathrm{ha}^{-1}+\text { quizalofop-p- } \\
\text { ethyl } 50 \mathrm{~g} \mathrm{ha}^{-1} \text { at } 15 \text { DAS as early PoE fb glyphosate } \\
71 \% \mathrm{SG} 2.13 \mathrm{~kg} \mathrm{ha}^{-1} \text { at } 45 \text { DAS }\end{array}$ & 124 & 70.97 & 2.71 \\
\hline $\begin{array}{l}\text { Pendimethalin } 1.0 \mathrm{~kg} \mathrm{ha}^{-1} \text { as PE fb HW at } 20 \text { and } 45 \\
\text { DAS }\end{array}$ & 109 & 75.81 & 3.18 \\
\hline Unweeded control & 86 & 40.43 & 1.48 \\
\hline S. Em \pm & 2.6 & 3.34 & 0.02 \\
\hline $\mathrm{CD}(\mathrm{P}=0.05)$ & 7.7 & 9.69 & 0.10 \\
\hline \multicolumn{4}{|l|}{ Interaction (D X W) } \\
\hline S. Em \pm & 5.3 & 6.67 & 0.05 \\
\hline
\end{tabular}

Table. 2 Yield, gross returns, net returns and B: C ratio of Bt cotton under varied Plant densities and weed management practices kharif, 2015

\begin{tabular}{|c|c|c|c|c|c|}
\hline Treatment & $\begin{array}{l}\text { Yield } \\
\mathrm{Kg} \mathrm{ha}^{-1}\end{array}$ & $\begin{array}{l}\mathrm{CC} \\
₹ \mathrm{ha}^{-1}\end{array}$ & $\begin{array}{l}\text { Gross } \\
\text { returns } \\
\text { ₹ ha }^{-1}\end{array}$ & $\begin{array}{l}\text { Net returns } \\
₹ \text { ha }^{-1}\end{array}$ & $\begin{array}{l}\mathrm{B}: \mathrm{C} \\
\text { ratio }\end{array}$ \\
\hline \multicolumn{6}{|l|}{ Plant densities (D) } \\
\hline $60 \mathrm{~cm} \times 30 \mathrm{~cm}(55,555)$ & 2184 & 41182 & 83009 & 41828 & 1.95 \\
\hline $60 \mathrm{~cm} \times 15 \mathrm{~cm}(1,11,111)$ & 3134 & 51886 & 119097 & 67212 & 2.24 \\
\hline $60 \mathrm{~cm} \times 15 \mathrm{~cm}(1,11,111$ Paired row- $45 \mathrm{~cm} \times 75 \mathrm{~cm})$ & 2595 & 51886 & 98585 & 46700 & 1.87 \\
\hline $45 \mathrm{~cm} \times 15 \mathrm{~cm}(1,48,148)$ & 2207 & 58943 & 83843 & 24901 & 1.39 \\
\hline S. Em \pm & 149.43 & & & 5678.51 & \\
\hline $\mathrm{CD}(\mathrm{P}=0.05)$ & 433.69 & & & 16480.07 & \\
\hline \multicolumn{6}{|l|}{ Weed Management Practices (W) } \\
\hline $\begin{array}{l}\text { Pendimethalin } 30 \% \text { EC } 1.0 \mathrm{~kg} \mathrm{ha}^{-1} \text { as PE fb PoE } \\
\text { pyrithiobac sodium } 62.5 \mathrm{~g} \mathrm{ha}^{-1}+\text { quizalofop-p-ethyl } \\
5 \% \text { EC } 50 \mathrm{~g} \mathrm{ha}^{-1} \text { at } 20,40,60 \mathrm{DAS}\end{array}$ & 3119 & 56566 & 118508 & 61942 & 2.11 \\
\hline $\begin{array}{l}\text { Pyrithiobac sodium } 10 \% \text { EC } 62.5 \mathrm{~g} \mathrm{ha}^{-1}+\text { quizalofop- } \\
\text { p-ethyl } 50 \mathrm{~g} \mathrm{ha}{ }^{-1} \text { at } 15 \mathrm{DAS} \text { as early PoE fb } \\
\text { glyphosate } 71 \% \mathrm{SG}_{2} .13 \mathrm{~kg} \mathrm{ha}^{-1} \text { at } 45 \mathrm{DAS}\end{array}$ & 3018 & 50154 & 114681 & 64,527 & 2.32 \\
\hline $\begin{array}{l}\text { Pendimethalin } 1.0 \mathrm{~kg} \mathrm{ha}^{-1} \text { as PE fb HW at } 20 \text { and } 45 \\
\text { DAS }\end{array}$ & 3058 & 53132 & 116200 & 63068 & 2.22 \\
\hline Unweeded control & 925 & 44042 & 35145 & -8897 & 0.80 \\
\hline S. Em \pm & 149.43 & & & 5678.51 & \\
\hline $\mathrm{CD}(\mathrm{P}=0.05)$ & 433.69 & & & 16480.07 & \\
\hline \multicolumn{6}{|l|}{ Interaction (D X W) } \\
\hline S. Em \pm & 298.87 & & & 11357.03 & \\
\hline $\mathrm{CD}(\mathrm{P}=0.05)$ & NS & & & NS & \\
\hline
\end{tabular}


The increased B: C ratio was attributed due to higher cotton yield, gross returns and net returns with comparatively lower cost of cultivation. Even though, the lowest yield was obtained from 55,555 plants $\mathrm{ha}^{-1}(60 \mathrm{~cm} \times 30$ $\mathrm{cm}$ ), the increased $\mathrm{B}$ : $\mathrm{C}$ ratio was due to reduced cost of cultivation when compared to other densities, where increased cost of cultivation was noticed due to increased population per unit area with reduced yield.

\section{Effect of weed management practices on economics}

Weed management practices also showed significant impact on profitability of Bt cotton under different weed management practices. Increased cost of cultivation and gross returns was recorded with sequential PE application of pendimethalin $1.0 \mathrm{~kg} \mathrm{ha}^{-1} \mathrm{fb}$ PoE tank mix application of pyrithiobac sodium $62.5 \mathrm{~g}$ ha

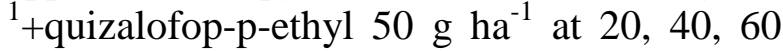
DAS. This was followed by IWM practice of pendimethalin $1.0 \mathrm{~kg} \mathrm{ha}^{-1}$ (PE) fb $\mathrm{HW}$ at 20 and 45 DAS and sequential early PoE tank mix application of pyrithiobac sodium $62.5 \mathrm{~g}$ ha $^{-1}$ +quizalofop-p-ethyl $50 \mathrm{~g} \mathrm{ha}^{-1}$ at 15 DAS $\mathrm{fb}$ directed spray of glyphosate ammonium salt $2.13 \mathrm{~kg} \mathrm{ha}^{-1}$ at 45 DAS. The lowest cost of cultivation and gross returns was recorded with unweeded control treatment. This might be due to effective control of weeds which reflected in less weed population, dry weight of weeds and maximum bolls plant ${ }^{-1}$, higher seed cotton yield and higher gross returns (Madhu et al., 2014).

Even though small reduction in kapas yield was observed with early PoE tank mix application of pyrithiobac sodium $62.5 \mathrm{~g}$ ha ${ }^{1}$ +quizalofop-p-ethyl $50 \mathrm{~g} \mathrm{ha}^{-1}$ at $15 \mathrm{DAS} \mathrm{fb}$ directed spray of glyphosate ammonium salt $2.13 \mathrm{~kg} \mathrm{ha}^{-1}$ at 45 DAS, but significantly higher net returns and $\mathrm{B}: \mathrm{C}$ ratio were obtained due to reduced cost of cultivation and was followed by pendimethalin $1.0 \mathrm{~kg} \mathrm{ha}^{-1}(\mathrm{PE}) \mathrm{fb}$
HW at 20 and 45 DAS and PE application of pendimethalin $1.0 \mathrm{~kg} \mathrm{ha}^{-1} \mathrm{fb}$ PoE tank mix application of pyrithiobac sodium $62.5 \mathrm{~g}$ ha ${ }^{1}$ +quizalofop-p-ethyl $50 \mathrm{~g} \mathrm{ha}^{-1}$ at 20, 40, 60 DAS. Least net returns and B: $\mathrm{C}$ ratio was obtained with unweeded control treatment. Interaction was not found significant under varied plant densities and weed management practices on net returns and $\mathrm{B}$ : $\mathrm{C}$ ratio.

In concluding remarks based on economic analysis, normal planting density of 1,11,111 plants $\mathrm{ha}^{-1}(60 \mathrm{~cm} X 15 \mathrm{~cm})$ is effective to realise higher kapas yield $\left(3134 \mathrm{~kg} \mathrm{ha}^{-1}\right)$ net returns of (Rs 67,212 $\mathrm{ha}^{-1}$ ) and B:C ratio (2.24 $\left.\mathrm{ha}^{-1}\right)$. Among the weed management practices sequential early PoE tank mix application of pyrithiobac sodium $62.5 \mathrm{~g} \mathrm{ha}^{-1}+$ quizalofop-pethyl $50 \mathrm{~g} \mathrm{ha}^{-1}$ at $15 \mathrm{DAS} \mathrm{fb}$ directed spray of glyphosate ammonium salt $2.13 \mathrm{~kg} \mathrm{ha}^{-1}$ at 45 DAS was effective to get higher kapas yield $\left(3018 \mathrm{~kg} \mathrm{ha}^{-1}\right.$ ), net returns (Rs.64,527 and $2.32 \mathrm{ha}^{-1}$ ) and $\mathrm{B}: \mathrm{C}$ ratio.

\section{References}

Madhu, G., K. Srinivasulu, P.P. Rani and Rao, A.S. 2014. Economics of rainfed $B t$ cotton as influenced by sequential application of herbicides. Journal of Cotton Research and Development. 28 (2): 257-259.

Narala, A., Reddy, A.R. 2011. Analysis of Growth and Instability of Cotton production in India. WCRC-5:449-453

Prabhu, G., A.S. Halepyati, B.T. Pujari and Desai, B.K. 2012.Weed management in Bt cotton (Gossypium hirsutum L.) under irrigation. Karnataka Journal of Agriculture Science. 25 (2): 183-186.

Pradeep Kumar, A.S. Karle, Deshraj Singh and Lalita Verma. 2017. Effect of High Density Planting System (HDPS) and Varieties on Yield, Economics and Quality of Desi Cotton. Int.J.Curr.Microbiol.App.Sci. 6(3): 233- 
238. doi: https://doi.org/10.20546/ ijcmas.2017.603.025

Srinivasulu, G and Rao, A.S. 2000. Effect of sequential application of herbicides on weed management in cotton. In: Proceedings of symposium on challenges in Agronomic crop management in early 21 st century organized by Society of Agronomists,
Hyderabad, May, 24-25. Pp. 71-74. Venugopalan, M.V., K.R. Kranthi, D. Blaise, L Shubhang and Sankaranarayana, K.2013. High density planting system in cotton -The Brazil Experience and Indian Initiatives. Cotton Research Journal. 5 (2): 172-185.

\section{How to cite this article:}

Madavi, B., P. Leela Rani, G. Sreenivas and Surekha, K. 2017. Effect of High Density Planting and Weed Management Practices on Productivity and Economic Analysis of Bt Cotton. Int.J.Curr.Microbiol.App.Sci. 6(7): 2225-2230. doi: https://doi.org/10.20546/ijcmas.2017.607.261 